\title{
A ORGANIZAÇÃo MUNDIAL DE COMÉRCIO E A PROLIFERAÇÃO DE ACORDOS REGIONAIS
}

Marden de Melo Barboza ${ }^{1}$

\section{I - Introdução}

Embora muitos países - sobretudo os mais pobres - questionem o atual modelo de comércio internacional, considerando-o muitas vezes injusto, é inegável que, na atualidade, poucos países podem se dar ao direito de adotar um modelo auto-suficiente de produção, abdicando das trocas comerciais por uma questão de princípios ou opções políticas. Esses e muitos outros aspectos presentes na atualidade contribuem para a constatação de que o comércio internacional assume, neste início de século XXI, importância que nunca teve na história, sobretudo em termos de potencial de avanço ${ }^{2}$.

Dados estatísticos da Organização Mundial de Comércio comprovam essa importância crescente, ao demonstrarem que, no período entre 1950 e 1994, os fluxos de comércio internacional, representados pela soma de exportações e importações, cresceram a uma taxa média anual de 6\%. Como resultado, em 1994 esses valores de comércio eram 14 vezes superiores aos de 1950 e, em 2002, haviam alcançado a marca histórica de US\$ 13,1 trilhões (WTO, 2003a).

Entretanto, o processo de aumento dos fluxos comerciais globais não ocorreu ao acaso. Foi antes o resultado de décadas de esforços e negociações que só foram possíveis, em grande medida, pela existência de arranjos internacionais diversos, com destaque para

\footnotetext{
${ }^{1}$ Professor do curso de Relações Internacionais do UNICEUB

${ }^{2}$ Boa parte dessa importância assumida pelo comércio internacional deve-se ao fato de que há uma percepção crescente de que o comércio é uma ferramenta fundamental para a obtenção de crescimento econômico em bases sustentadas. Dessa forma, diversos estudos vêm ressaltando a relação direta existente entre crescimento econômico e abertura ao mercado externo. Estudos de Frankel e Romer, citados por Collier, por exemplo, afirmam que "openess as measured by the share of trade in income is robustly related to long term growth" (Dollar, 2001: 37).
}

Universitas - Relações Int., Brasília, v. 2, n.1, p. 59-101, jan./jun. 2004 
o Acordo Geral sobre Tarifas de Comércio $\left(\right.$ GATT $\left.^{3}\right)$ e para a Organização Mundial do Comércio (OMC), esta última a partir de 1995. A partir da instituição do GATT, na década de 1940, foi possível conformar um arcabouço jurídico supranacional que estabeleceu regras internacionais lineares e transparentes, conferindo maior segurança e previsibilidade nas relações comerciais entre países.

Em 1994, ao final da Rodada Uruguai, decidiu-se pelo estabelecimento de uma maior institucionalização e pelo aumento do escopo das negociações, o que resultou na incorporação do GATT pela recém criada Organização Mundial do Comércio (OMC). Com essa nova organização, concebida no auge da terceira grande onda de liberalização comercial (Collier, 2001:24), buscou-se dar continuidade à bem sucedida experiência do GATT, com incorporação de todos os instrumentos jurídicos aprovados no âmbito desse acordo.

Em linhas gerais, nos anos que se seguiram à criação da $\mathrm{OMC}$ foram estabelecidas duas grandes linhas de ação. Em uma primeira, buscou-se integrar os países em desenvolvimento ao processo de abertura de mercados, que vinha sendo implementado com relativo sucesso desde o final da década de 1940. Conforme se demonstrará ao longo do presente estudo, boa parte desses países mantiveram-se à margem do processo de abertura comercial ocorrido sob os auspícios do GATT e, por isso, no início da década de 90 esses países menos desenvolvidos $^{4}$ ainda encontravam-se, na média, muito fechados ao comércio internacional.

Além disso, em uma segunda linha de ação, a criação da OMC abriu espaço para a realização de negociações em diversos novos temas. As negociações realizadas no âmbito do GATT eram, via de regra, negociações voltadas para a redução de tarifas ao comércio exterior. Com a criação da OMC abriu-se espaço para a discussão de outros temas, com destaque para as regulamentações sobre serviços, compras governamentais, propriedade intelectual e medidas de defesa comercial.

\footnotetext{
${ }^{3}$ General Agreement on Tariffs and Trade

${ }^{4}$ Para os propósitos deste estudo, os países menos desenvolvidos abarcam o conjunto de todos aqueles países que não são considerados desenvolvidos. Esse termo não é utilizado, portanto, para se referir aos chamados "países pobres".
}

Universitas - Relações Int., Brasília, v. 2, n.1, p. 59-101, jan./jun. 2004 
Entretanto, a despeito da sólida herança recebida do GATT, os anos que sucederam a conclusão da Rodada Uruguai (1994) não foram auspiciosos para a OMC. Ao contrário, as novas rodadas de negociação patrocinadas por esse novo órgão pouco avançaram em relação ao que já havia sido acordado anteriormente. Esse e outros fatos acabaram por criar um sentimento generalizado de incerteza quanto aos rumos do sistema multilateral de comércio.

Nesse cenário de incerteza, tem-se observado o surgimento de um grande número de acordos regionais ou bilaterais de comércio. Dados da própria OMC demonstram que, até dezembro de 2002, cerca de 250 acordos regionais de livre comércio foram notificados àquele órgão (WTO, 2003b). O que mais chama a atenção, neste caso, é que a maior parte desses acordos são de criação recente, coincidindo com o período posterior à criação da OMC. A título de exemplo, dos 250 acordos regionais de livre comércio citados anteriormente, 130, ou mais da metade (52\%), foram notificados após janeiro de 1995 (WTO, 2003b).

Os dados acima demonstram, portanto, o forte crescimento no número de acordos regionais. Ao longo dos 47 anos de funcionamento do GATT, (1948-1994) foram realizadas cerca de 120 notificações de acordos regionais, contra 130 notificações nos últimos sete anos. Mais sintomático ainda é o fato de que as perspectivas futuras não indicam reversão nessa tendência. Ao contrário, estimativas recentes dão conta de que, em pouco tempo, existirão mais de 300 desses acordos regionais vigentes no mundo (Mello, 2003)

Esse cenário de proliferação dos acordos de livre comércio, verificado com maior intensidade a partir do início da década de 1990, cria uma nova dinâmica no comércio internacional, vista de forma preocupante por expoentes do pensamento econômico como o indiano Jagdish Bhagwati ${ }^{5}$. De acordo com os pontos de vista desse e de outros autores, a possibilidade - criada pelos acordos regionais - de que um país mantenha trato diferenciado a outros países, enseja a formação de um modelo perverso, que pode destruir as estruturas montadas pela OMC, em detrimento dos países mais pobres (Bhagwati, 2003).

\footnotetext{
${ }^{5}$ Considerado o maior especialista do mundo em comércio internacional, Jagdish Bhagwati leciona atualmente na Universidade de Columbia, EUA (Mello, 2003).
}

Universitas - Relações Int., Brasília, v. 2, n.1, p. 59-101, jan./jun. 2004 
Ainda de acordo com Bhagwati, a "epidemia" dos acordos bilaterais é uma ameaça "de morte" à OMC e à inserção dos países mais pobres no sistema internacional de comércio (Mello, 2003). De acordo com esse autor, os acordos bilaterais estão destruindo o conceito de nação mais favorecida, considerado por ele como fundamental para a eficácia do sistema multilateral de comércio. A multiplicidade de acordos, com preferências tarifárias e regras diferenciadas, está criando um caos sistêmico, identificado por ele como "uma travessa cheia de espaguete emaranhado" (Mello, 2003).

Diante desses aspectos, como explicar a proliferação desses acordos bilaterais, em detrimento do sistema multilateral de comércio que por tantos anos funcionou a contento? Que fatores explicam a recente tendência de criação de novos acordos localizados e a recusa da maioria dos países em avançar nas negociações multilaterais já em curso no âmbito da OMC?

Buscando equacionar essa questão, o trabalho a seguir se dividirá em duas grandes partes. Em uma primeira, serão analisadas as três grandes ondas de liberalização comercial, com breves análises sobre seus impactos junto aos países desenvolvidos e aos em desenvolvimento. Diante do importante papel que os países em desenvolvimento desempenham nas negociações comerciais contemporâneas, nessa primeira parte será explorado com maior detalhe o processo de abertura comercial ocorrido no âmbito desses países, a partir de meados da década de 80. Em uma segunda parte, será analisada a compatibilidade jurídica entre os acordos regionais e as normas gerais do sistema GATT/OMC. A partir dessa análise, serão apresentados os possíveis fatores que têm provocado o surgimento e a proliferação de acordos de livre comércio nos anos mais recentes. Dessa forma, três aspectos serão destacados como possíveis explicações para esse fenômeno: a inclusão de novos temas nos debates da OMC, a mudança no cenário político internacional e, por último, a necessidade de acomodar interesses domésticos nas negociações externas.

Universitas - Relações Int., Brasília, v. 2, n.1, p. 59-101, jan./jun. 2004 


\section{II - Histórico}

Para uma correta compreensão dos fenômenos atuais na área do comércio internacional, convém analisar a evolução das trocas comerciais a partir de uma perspectiva histórica. Além de permitir uma melhor compreensão dos fatores que motivaram e construíram o cenário atual, com essa análise histórica pretende-se identificar as tendências de longo prazo dos fenômenos mais marcantes da atualidade.

Para essa análise histórica, a evolução do comércio mundial foi segmentada em três grandes momentos ou ondas liberalizantes (Collier, 2001). Embora dentro desses três grupos possam ser encontradas situações momentâneas ou localizadas que destoem do contexto geral, e que talvez merecessem uma análise em separado, o entendimento desses três grandes momentos é suficiente para os propósitos deste estudo, por fornecer um panorama suficientemente amplo para a compreensão da evolução do comércio internacional até os dias de hoje. De acordo com Paul Collier (2001:23), o primeiro desses grandes períodos vai da segunda metade do século XIX ao início da Primeira Grande Guerra $(1914)^{6}$. O segundo inicia-se com a realização da conferência mundial de Bretton Woods, em 1944, e vai até meados da década de 80 . O terceiro dos períodos, que será analisado com maior detalhes, vai dessa década aos tempos atuais.

\section{II.1 - $1^{\circ}$ Período de liberalização comercial - 1870 - 1914}

Apesar do comércio já estar presente em menor medida antes do século XIX, o primeiro grande surto de comércio internacional, impulsionado pelas idéias liberalizantes de Adam Smith e David Ricardo, desenvolveu-se no rastro da Revolução Industrial e dos ganhos de produtividade proporcionados por ela no mundo desenvolvido da época, em especial na Inglaterra. Ao longo desse

\footnotetext{
${ }^{6}$ Entre 1914 e 1944 houve uma interrupção no processo liberalizante que vinha ocorrendo desde a segunda metade do século XIX. Cria-se por isso um hiato temporal em que não houve liberalização comercial mas, ao contrário, um forte movimento protecionista em escala mundial.
}

Universitas - Relações Int., Brasília, v. 2, n.1, p. 59-101, jan./jun. 2004 
período de quase 50 anos, que compreendeu o final do século XIX e as duas primeiras décadas do século XX, até aproximadamente 1914, houve uma evolução significativa no volume do comércio mundial ${ }^{7}$, que alcançou patamares elevados mesmo para os níveis atuais.

Nessa primeira era dourada do comércio e do desenvolvimento, o incremento nas trocas internacionais caracterizouse, sobretudo, por uma forte influência do sistema cambial de padrãoouro e por uma expressiva participação dos produtos primários nas trocas entre os países. Além disso, as relações comerciais foram conduzidas de forma livre, sem o patrocínio de nenhuma grande organização internacional. Em termos nacionais, também foi característica desse período a elevada participação do comércio internacional em relação ao produto interno, conforme será detalhado adiante.

Diante da forte hegemonia econômica da Inglaterra e da força dos argumentos econômicos favoráveis à especialização internacional da produção, estabeleceu-se nesse período um sistema que propunha uma divisão internacional do trabalho baseada em produtores de bens industrializados, de um lado, e produtores de bens primários, de outro. Esse modelo ficou conhecido como workshops versus granaries.

Esse ciclo de prosperidade foi interrompido por um movimento de forte instabilidade nas políticas tarifárias globais, que iniciou-se a partir de 1914 e que se fortaleceu com a eclosão da Grande Depressão, na década de 1930, perdurando até meados da década de 40. Esse processo teve como resultado, entre outras coisas, a realização de desvalorizações cambiais competitivas entre os principais países e a adoção de fortes políticas protecionistas. Um dos principais exemplos dessa última tendência foi a promulgação da Lei Smoot-Hawley, nos Estados Unidos na década de 1930, que aumentou as tarifas de importação sobre alguns produtos em até $1.000 \%$ (Bhagwati, 1989: 41).

Essa sucessão de desvalorizações competitivas e políticas protecionistas, somada às duas Guerras Mundiais e à Grande

\footnotetext{
${ }^{7}$ No início do século XIX, o volume de comércio internacional representava aproximadamente $3 \%$ do produto mundial. Por volta de 1914, já havia se elevado para cerca de $33 \%$.
}

Universitas - Relações Int., Brasília, v. 2, n.1, p. 59-101, jan./jun. 2004 
Depressão, resultaram no desmonte das relações comerciais que haviam sido construídas em décadas anteriores. Como resultado, o nível de participação do comércio em relação ao PIB, existente em 1913, só foi recuperado na maior parte dos países a partir das décadas de 60 e 70. Além disso, como demonstra Feenstra (2000:146), esse período experimentou um processo de abertura comercial tão significativo que até a década de 90 alguns países como Austrália, Dinamarca, Japão e Reino Unido, ainda não haviam alcançado os níveis de comércio obtidos em $1913^{8}$. Os números abaixo detalham essa situação:

\section{Tabela 1 - Razão do comércio de bens em relação ao PIB (Percentagem)}

\begin{tabular}{||c|c|c|c|c|c|c||}
\hline País & $\mathbf{1 8 9 0}$ & $\mathbf{1 9 1 3}$ & $\mathbf{1 9 6 0}$ & $\mathbf{1 9 7 0}$ & $\mathbf{1 9 8 0}$ & $\mathbf{1 9 9 0}$ \\
\hline Austrália & 15,70 & 21,00 & 13,00 & 11,50 & 13,60 & 13,40 \\
\hline Canada & 12,80 & 17,00 & 14,50 & 18,00 & 24,10 & 22,00 \\
\hline Dinamarca & 24,00 & 30,70 & 26,90 & 23,30 & 26,80 & 24,30 \\
\hline Japão & 5,10 & 12,50 & 8,80 & 8,30 & 11,80 & 8,40 \\
\hline Reino Unido & 27,30 & 29,80 & 15,30 & 16,50 & 20,30 & 20,60 \\
\hline Estados Unidos & 5,60 & 6,10 & 3,40 & 4,10 & 8,80 & 8,00 \\
\hline
\end{tabular}

Fonte: Feenstra (2000: 146)

\section{II.2 - $2^{\circ}$ Período de liberalização comercial (1944 - 1980)}

O ambiente de incerteza que se seguiu ao crack da bolsa de Nova Iorque, em 1929, só foi revertido quando, às vésperas do fim da Segunda Guerra Mundial, em 1944, delegados de 45 nações capitalistas reuniram-se em Bretton Woods, Estados Unidos, para lançar as bases de um novo sistema internacional que fornecesse as condições institucionais necessárias à estabilidade monetária e à

\footnotetext{
${ }^{8}$ Como esse mesmo autor observa, parte dessa dificuldade em retomar os níveis de 1913 pode ser explicado pelo aumento na participação dos serviços na composição do PIB. Também ao longo desses anos, aumentaram significativamente as despesas governamentais, o que contribuiu para reduzir, em termos comparativos, os valores de comércio em relação ao PIB.
}

Universitas - Relações Int., Brasília, v. 2, n.1, p. 59-101, jan./jun. 2004 
prosperidade econômica mundial. Buscava-se, com a realização dessa conferência, o estabelecimento de uma nova ordem institucional que fornecesse regras claras sob as quais "as forças de mercado pudessem atuar, permitindo a previsibilidade das estratégias de investimento empresariais" (Gonçalves, 1998: 55). Com base nessas premissas, foi proposta a criação do Fundo Monetário Internacional (FMI), encarregado dos aspectos relacionados à política cambial e de balança de pagamentos, do Banco Mundial (BIRD), que estimularia o desenvolvimento econômico, e da Organização Internacional do Comércio (OIC), que buscaria regulamentar e estimular o comércio internacional entre os países membros.

Após a recusa do Congresso norte-americano em ratificar a OIC, por entender que essa organização reduzia a autonomia norteamericana em negociar isoladamente com os demais países, optou-se por um mecanismo mais flexível, que permitisse a negociação de reduções tarifárias em bases menos formais. Dessa forma, em 01 de janeiro de 1948 entrou em vigência o Acordo Geral de Tarifas e Comércio, conhecido mundialmente como GATT, que incorporou parte das decisões que haviam sido acordadas no âmbito da OIC, em $1947^{9}$.

Sob os auspícios do GATT, e em razão das diversas rodadas de negociação por ele promovidas, o mundo capitalista experimentou, nas décadas seguintes, um crescimento do comércio internacional sem precedentes na história. Em quase cinqüienta anos de existência ${ }^{10}$, o GATT contribuiu para promover a expansão do comércio mundial a níveis significativos. Entre 1950 e 1990 o comércio de mercadorias deu um importante salto, aumentado cerca de 10 vezes em volume e aproximadamente 50 vezes em valor (WTO, 2003a). Esse incremento nas transações comerciais foi possível, em grande medida, pela significativa redução nas tarifas ao comércio exterior. Nos países desenvolvidos, por conta da atuação do GATT, as barreiras tarifárias

\footnotetext{
9 Em verdade, o acordo do GATT foi extraído, com algumas modificações, do capítulo de Política Comercial da Carta de Havana, que propunha a criação da OIC.

${ }^{10}$ Período compreendido entre a entrada em vigência do GATT, em janeiro de 1948 e a assinatura do Acordo de Marrakesh, ao final da Rodada Uruguai, em 1994.
}

Universitas - Relações Int., Brasília, v. 2, n.1, p. 59-101, jan./jun. 2004 
reduziram-se, em média, de 40\%, na década de 1940, para cerca de 5\% em meados da década de 90 (Wathen, 1996: 23).

Contribuíram também para a expansão do comércio nesse segundo período de liberalização, além da redução parcial nas barreiras comerciais, uma redução contínua nos custos de transporte (Collier, 2001: 24). Esse processo engendrou a criação de uma segunda era dourada no comércio internacional, que propiciou ganhos, sobretudo, para os países desenvolvidos. Esses países aumentaram significativamente suas trocas comerciais, desenvolvendo um processo de ampla abertura comercial entre si ao mesmo tempo que mantinham barreiras a alguns produtos - especialmente os agrícolas - provenientes de países em desenvolvimento, que pudessem competir com sua produção doméstica (Collier, 2001: 28).

Os países em desenvolvimento, por outro lado, não participaram, ou participaram de forma limitada, desse crescimento global no comércio de bens e serviços. Em geral, esses países mantiveram-se relativamente fechados à entrada de produtos importados, ao mesmo tempo em que continuavam dependentes da exportação de produtos primários como fonte principal de receitas. A título de exemplo, em 1980 apenas $25 \%$ das exportações de mercadorias dos países em desenvolvimento eram compostas por produtos industrializados (Collier, 2001: 28).

\section{II.3 - $3^{\circ}$ Período de liberalização comercial (1980 aos dias atuais)}

O terceiro momento na evolução do comércio internacional, ainda em curso, iniciou-se em meados da década de 80 e caracterizouse por uma diminuição no ritmo da abertura comercial que vinha ocorrendo nos países desenvolvidos, sob o patrocínio do GATT, desde o final da década de 40. Ao mesmo tempo em que o processo de redução de tarifas, no âmbito dos países desenvolvidos, chegava a uma situação de limite, verificou-se nesses mesmos países uma retomada dos sentimentos protecionistas, que implicaram em um maior uso de barreiras não tarifárias ao comércio, fato que não ocorria de forma intensa desde o período da grande depressão, no entre-guerras.

Universitas - Relações Int., Brasília, v. 2, n.1, p. 59-101, jan./jun. 2004 
Em 1987, quando o efeito total das reduções tarifárias da Rodada Tóquio se fez sentir, as tarifas dos países desenvolvidos encontravam-se em patamares extremamente baixos. Entretanto, como observa Gonçalves, enquanto as barreiras tarifárias nos países desenvolvidos reduziam-se, "entre 1980 e 1990 as BNTs (barreiras não-tarifárias) cresceram continuamente, sendo que, em 1990, 17,5\% do comércio mundial de todas as origens era coberto por medidas não tarifárias"(Gonçalves, 1998: 60).

Apesar da diminuição no ritmo de reduções tarifárias e do aumento no uso de barreiras não-tarifárias ao comércio, dois processos mantiveram-se em andamento. Primeiramente, o comércio continuou sendo um potente mecanismo dinamizador da economia mundial. Para os países da OCDE, ao longo das décadas de 80 e 90, o crescimento do comércio em relação ao Produto Interno (PIB) continuou sendo significativo (Feenstra, 2000: 144). Nos Estados Unidos, por exemplo, o peso das exportações e importações em relação ao PIB continuou crescendo, embora em um ritmo menor que o verificado em décadas anteriores, como pode ser verificado na tabela abaixo.

Tabela 2 - Evolução do PIB e do Comércio Exterior dos Estados Unidos

Valores em US\$ bilhões

\begin{tabular}{||c|c|c|c|c|c||}
\hline \hline Estados Unidos & $\mathbf{1 9 6 0}$ & $\mathbf{1 9 7 0}$ & $\mathbf{1 9 8 0}$ & $\mathbf{1 9 9 0}$ & $\mathbf{1 9 9 9}$ \\
\hline & & & & & \\
\hline PIB & 527,4 & 1.039 & $2.795,6$ & $5.803,2$ & $9.299,2$ \\
\hline & & & & & \\
\hline Exportações & 25,3 & 57 & 278,9 & 557,2 & 1031,5 \\
\hline Importações & 22,8 & 55,8 & 293,8 & 628,6 & $1.253,1$ \\
\hline & & & & & \\
\hline Exportações/PIB(\%) & $4,80 \%$ & $5,48 \%$ & $9,98 \%$ & $9,60 \%$ & $11,09 \%$ \\
\hline Importações/PIB (\%) & $4,32 \%$ & $5,37 \%$ & $10,51 \%$ & $10,83 \%$ & $13,47 \%$ \\
\hline
\end{tabular}

Fonte: U.S. Government (2000)

Universitas - Relações Int., Brasília, v. 2, n.1, p. 59-101, jan./jun. 2004 
O segundo aspecto a ser observado está relacionado à modificação na pauta de comércio dos países desenvolvidos. Ao longo dos últimos 50 anos, e de forma mais acentuada durante as décadas de 80 e 90, verificou-se um movimento de aumento nas exportações de serviços, ao mesmo tempo em que houve um crescimento nas importações de bens de consumo. Esse fenômeno sugere uma tendência, nos países desenvolvidos, de migração para atividades do setor terciário, com o abandono da produção de alguns bens tradicionais, que passaram a ser importados de países de industrialização mais recente. Esse processo pode ser observado por meio das estatísticas de importação e exportação norte-americanas, conforme detalhado abaixo.

Tabela 3 - Exportações Norte-Americanas - Valores em US\$ bilhões

\begin{tabular}{||c|c|c|c|c|c||}
\hline Ano & Total & Bens & \%* & Serviços & \% * \\
\hline $\mathbf{1 9 6 0}$ & 25,3 & 20,5 & $\mathbf{8 1 , 0 3 ~ \%}$ & 4,8 & $\mathbf{1 8 , 9 7 ~ \%}$ \\
\hline $\mathbf{1 9 7 0}$ & 57 & 44,5 & $\mathbf{7 8 , 0 7} \%$ & 12,4 & $\mathbf{2 1 , 7 5} \%$ \\
\hline $\mathbf{1 9 8 0}$ & 278,9 & 225,8 & $\mathbf{8 0 , 9 6} \%$ & 53,2 & $\mathbf{1 9 , 0 7} \%$ \\
\hline $\mathbf{1 9 9 0}$ & 557,2 & 398,5 & $\mathbf{7 1 , 5 2} \%$ & 158,6 & $\mathbf{2 8 , 4 6} \%$ \\
\hline $\mathbf{1 9 9 9}$ & 1031,5 & 726,5 & $\mathbf{7 0 , 4 3} \%$ & 305 & $\mathbf{2 9 , 5 7} \%$ \\
\hline
\end{tabular}

(*) Percentagem em relação ao valor total Fonte: U.S. Government (2000)

Tabela 4 - Importações Norte-Americanas - Em US\$ bilhões

\begin{tabular}{||c|c|c|c|c|c||}
\hline Ano & Total & Bens & \%* & Serviços & \% * \\
\hline $\mathbf{1 9 6 0}$ & 22,8 & 15,2 & $\mathbf{6 6 , 6 7} \%$ & 7,6 & $\mathbf{3 3 , 3 3} \%$ \\
\hline $\mathbf{1 9 7 0}$ & 55,8 & 40,9 & $\mathbf{7 3 , 3 0} \%$ & 14,9 & $\mathbf{2 6 , 7 0} \%$ \\
\hline $\mathbf{1 9 8 0}$ & 293,8 & 248,6 & $\mathbf{8 4 , 6 2} \%$ & 45,3 & $\mathbf{1 5 , 4 2} \%$ \\
\hline $\mathbf{1 9 9 0}$ & 628,6 & 508 & $\mathbf{8 0 , 8 1} \%$ & 120,6 & $\mathbf{1 9 , 1 9} \%$ \\
\hline $\mathbf{1 9 9 9}$ & 1253,1 & 1048,9 & $\mathbf{8 3 , 7 0} \%$ & 204,2 & $\mathbf{1 6 , 3 0} \%$ \\
\hline
\end{tabular}

(*) Percentagem em relação ao valor total

Fonte: U.S. Government (2000)

Universitas - Relações Int., Brasília, v. 2, n.1, p. 59-101, jan./jun. 2004 


\section{II.4 - A abertura comercial nos países em desenvolvimento}

Conforme já assinalado anteriormente, pode-se afirmar que a liberalização via OMC foi mais marcante nos países desenvolvidos. Nos países em desenvolvimento ${ }^{11}$ o processo de inserção no comércio mundial apresentou características diferentes das observadas nos países desenvolvidos. Por esse motivo, o processo ocorrido nesses países será analisado em destaque.

Por conta da grande diversidade política e econômica existente no âmbito dos países em desenvolvimento, as causas que motivam uma maior abertura comercial, para esse conjunto de países, são bastante heterogêneas, muitas vezes relacionadas a decisões isoladas de cada país que não acompanham uma tendência geral. Além disso, a abertura comercial observada nos países em desenvolvimento, por não seguir uma relação de causa e efeito homogênea, também ocorreu em momentos distintos, mesmo em países com características similares ou próximas.

Apesar dessas dificuldades em estabelecer generalizações, é possível concluir, inicialmente, que os países em desenvolvimento sempre foram, em geral, menos abertos ao comércio exterior que os desenvolvidos $^{12}$. Na América do Sul, por exemplo, Brasil e Chile foram os únicos que, em 1947, firmaram o acordo do GATT. Além disso, Bolívia, Costa Rica, El Salvador, México, Venezuela e Paraguai só consolidaram suas tarifas na OMC ao final da Rodada Uruguai, como parte dos compromissos de ingresso nessa organização (CEPAL, 1999).

Ao longo das últimas décadas, entretanto, esse distanciamento em relação aos fluxos mundiais de comércio se modificou e houve, sobretudo ao longo das décadas de 80 e 90, um progressivo movimento de redução de tarifas e retirada dos entraves ao comércio exterior, que

${ }^{11}$ Conforme dito anteriormente, para os propósitos deste trabalho não será feita distinção entre países menos desenvolvidos, em desenvolvimento ou de economias em transição. A distinção básica será entre países desenvolvidos versus países em desenvolvimento.

${ }^{12}$ Considerando-se apenas países independentes ou autônomos.

Universitas - Relações Int., Brasília, v. 2, n.1, p. 59-101, jan./jun. 2004 
tiveram como conseqüência um aumento significativo do comércio exterior no âmbito desses países.

Dados da Organização Mundial de Comércio, conforme apresentado nas tabelas a seguir, demonstram que as exportações totais da América Latina, que em 1980 alcançavam US\$ 109,7 bilhões, saltaram para US\$ 297 bilhões em 1999, o que significou um crescimento de $170 \%$ nas vendas externas ao longo de duas décadas. $\mathrm{Na}$ Ásia, excluído o Japão, as exportações cresceram ainda mais, indo de US\$ 193,1 bilhões, em 1980, para US\$ 1.126,4 bilhões, em 1999 $\left(\right.$ WTO, 2003) ${ }^{13}$. Dados publicados pela CEPAL (1999: 25) indicam ainda que, entre 1985 e 1999, as exportações latino-americanas aumentaram a uma razão média anual de $9 \%$ em volume e $10 \%$ em valor $^{14}$. Essas taxas só foram superadas pela China e os seis países mais dinâmicos da Ásia, que aumentaram suas exportações, em volume e valor, a uma taxa anual de $15 \%$ e $10,5 \%$, respectivamente. Para que se tenha uma idéia do que isso representou, no mesmo período as exportações do Japão cresceram a uma taxa anual de 2,5\% (CEPAL, 1999: 26).

Tabela 5 - Exportações Mundiais de Bens - Valores em US\$ bilhões

\begin{tabular}{||c|c|c|c|c|c||}
\hline & $\mathbf{1 9 8 0}$ & $\mathbf{1 9 8 5}$ & $\mathbf{1 9 9 0}$ & $\mathbf{1 9 9 5}$ & $\mathbf{1 9 9 9}$ \\
\hline América Latina & 109,70 & 108,50 & 146,80 & 228,70 & 297,00 \\
\hline África & 120,80 & 81,00 & 104,10 & 107,30 & 112,10 \\
\hline Ásia* & 193,16 & 239,24 & 504,72 & 1001,38 & 1126,34 \\
\hline Participação*** & $20,82 \%$ & $21,98 \%$ & $21,95 \%$ & $26,34 \%$ & $27,30 \%$ \\
\hline Mundo & $2.035,00$ & $1.951,00$ & $3.442,00$ & $5.078,00$ & $5.625,00$ \\
\hline
\end{tabular}

(*) Excluído Japão

(**) Participação da América Latina, África e Ásia no total mundial Fonte: WTO, 2003a

\footnotetext{
13 Apesar desses avanços, as exportações africanas se mantiveram praticamente estagnadas ao longo dessas duas décadas (WTO, 2003a).

${ }^{14}$ Esse desempenho se deveu, em grande parte, ao crescimento do comércio exterior do México, que experimentou ao longo da década de 90 uma das mais altas taxas de aumento de comércio do mundo. Ao mesmo tempo, em alguns anos os demais países da América Latina experimentavam taxas modestas ou mesmo negativas (WTO, 2003a).
}

Universitas - Relações Int., Brasília, v. 2, n.1, p. 59-101, jan./jun. 2004 
Tabela 6 - Importações Mundiais de Bens - Valores em US\$ bilhões

\begin{tabular}{||c|c|c|c|c|c||}
\hline & $\mathbf{1 9 8 0}$ & $\mathbf{1 9 8 5}$ & $\mathbf{1 9 9 0}$ & $\mathbf{1 9 9 5}$ & $\mathbf{1 9 9 9}$ \\
\hline América Latina & 123,40 & 84,50 & 130,20 & 254,00 & 334,70 \\
\hline África & 96,80 & 69,50 & 94,80 & 125,60 & 132,50 \\
\hline Ásia* & 210,104 & 258,512 & 526,832 & $1.065,318$ & $1.040,338$ \\
\hline Participação** & $20,75 \%$ & $20,53 \%$ & $21,23 \%$ & $27,70 \%$ & $25,63 \%$ \\
\hline Mundo & $2.074,00$ & $2.009,00$ & $3.542,00$ & $5.216,00$ & $5.881,00$ \\
\hline
\end{tabular}

Ao mesmo tempo em que os países em desenvolvimento gradativamente participaram de forma mais intensa do comércio exterior, houve uma importante modificação na pauta de comércio desses países. Em termos gerais, houve crescimento na exportação de manufaturados, em contraposição à tradição histórica de venda de commodities agrícolas. Destaca-se também o aumento na importação de insumos e bens de capital.

Como conseqüência desse processo, ao longo da década de 80 e início da década de 90 as exportações de manufaturados desses países aumentaram "quase duas vezes mais rapidamente do que suas exportações recíprocas, registrando uma taxa anual de crescimento de mais de oito por cento" (Bhagwati,1989: 53). Obviamente, conforme dito no início deste tópico, esse processo não foi homogêneo, e alguns países ou regiões tiveram uma performance melhor que outras. Dessa forma, pode-se dizer que os casos mais marcantes de aumento do comércio internacional, nas décadas de 80 e 90, restringiram-se às principais economias do Leste e Sudeste Asiático $^{15}$ e alguns países latino-americanos, como o México.

\footnotetext{
${ }^{15}$ Coréia, Taiwan, Singapura e Malásia e, mais recentemente, Tailândia, Indonésia e China.
}

Universitas - Relações Int., Brasília, v. 2, n.1, p. 59-101, jan./jun. 2004 


\section{II.5 - Inserção dos países em desenvolvimento e seus fatores motivantes}

Esse movimento de abertura e maior inserção no comércio mundial dos países em desenvolvimento, ocorrido nas décadas mais recentes, pode ser creditado a um grande número de fatores. Em muitos casos, conforme dito anteriormente, estiveram em jogo circunstâncias conjunturais ou políticas localizadas, peculiares a determinados países, que não se conformaram ao todo ou não obedeceram uma lógica universal ou mesmo regional. Apesar das dificuldades em estabelecer generalizações, dois fatores causadores desse processo, de grande abrangência e importância para os países em desenvolvimento, merecem ser analisados.

Em primeiro lugar, o contexto de endividamento externo, falência do modelo de substituição de importações e fragilidade econômica que se verificou em grande parte dos países em desenvolvimento ao longo dos anos 80 e início dos 90 - especialmente nos latino-americanos - levou esses países a se submeterem a um rígido programa de ajuste fiscal e de reformas econômicas, elaborado e monitorado, na maior parte das vezes, pelo FMI e pelo Banco Mundial. Com base em princípios liberais, esses programas de ajuste, baseados nas diretrizes do Consenso de Washington, propuseram, entre outros, a redução do déficit público, a reavaliação do papel intervencionista do estado - o estado empreendedor -, a diminuição dos subsídios ao investimento e ao consumo e a eliminação das restrições ao comércio exterior (Pereira, 1996: 45). Como descreviam seus formuladores, buscava-se com isso implementar reformas orientadas para o mercado e coordenadas pelo Estado.

Além dos ajustes estruturais descritos acima, a crise da dívida dos anos 80 também forçou esses países a renunciarem aos direitos de não-reciprocidade que haviam obtido em Rodadas anteriores da OMC - especialmente a Rodada Tóquio - estabelecendo com isso sistemas aduaneiros com menos exceções. Estudo patrocinado pela OMC descreve as conseqüências desse processo para os países em desenvolvimento:

Universitas - Relações Int., Brasília, v. 2, n.1, p. 59-101, jan./jun. 2004 
"Many developing countries have applied $M F N^{16}$ rates which are substantially below their bound levels ("ceiling" bindings) as a result of unilateral or autonomous rate reductions in the last 10-20 years under structural adjustment programmes supported by the World Bank and the IMF (Laird, 1998: 1).”

Apesar desse novo enfoque, em alguns países - especialmente os do Leste e Sudeste Asiático - o Estado continuou desempenhando um papel importante na promoção do desenvolvimento. Uma explicação para essa estratégia, conforme descrito por Pereira (1996: 73), é que os asiáticos conseguiram combinar uma severa disciplina fiscal com alto grau de intervenção do Estado, ao mesmo tempo em que deixavam claro que suas economias eram "orientadas para o mercado". De acordo com Seiji Naya, citado por Pereira (1996: 74), apesar de nesses países o governo intervir fortemente, eles permitiram que o mercado funcionasse livremente, e adotaram uma abordagem liberal para o desenvolvimento econômico.

Um segundo fator que induziu a uma maior abertura comercial no âmbito dos países em desenvolvimento foi o papel desempenhado pelos regimes regionais e multilaterais de promoção do comércio, entre os quais se destaca o sistema GATT/OMC. Por conta das negociações realizadas nas Rodadas Tóquio e Uruguai, ao longo dos anos 80 e $90^{17}$ sucessivas reduções tarifárias foram implementadas, especialmente no âmbito dos países em desenvolvimento ${ }^{18}$. Assim, patamares tarifários muito elevados foram reduzidos, com a adoção de estruturas tarifárias mais uniformes. Além disso, nessas duas Rodadas foram realizados

\footnotetext{
${ }^{16}$ O texto do GATT de 1947 estabelece, em seu artigo I, o princípio da "Nação Mais Favorecida"” (MFN), que busca garantir que qualquer privilégio ou vantagem concedida por um país a um outro seja, imediatamente, concedida a todos os seus membros da mesma maneira.

${ }_{17}$ Para a maior parte das reduções tarifárias negociadas na Rodada Uruguai, a implementação se deu, a partir de 1995, em 5 anos para manufaturados e 6 anos para produtos agrícolas. Para a implementação desse último conjunto de produtos, os países em desenvolvimento dispuseram de 10 anos.

${ }_{18}$ Por ocasião da Rodada Uruguai, os patamares tarifários dos países desenvolvidos já se encontravam bem abaixo daqueles verificados nos demais países. A principal demanda dos países em desenvolvimento foi no campo dos produtos agrícolas e das barreiras não tarifárias ao comércio.
}

Universitas - Relações Int., Brasília, v. 2, n.1, p. 59-101, jan./jun. 2004 
esforços de eliminação ou harmonização da maioria das medidas administrativas e não tarifárias (NTM) que incidiam sobre o comércio, de grande importância para os países em desenvolvimento pelo fato de que essas medidas, como afirmou um estudo patrocinado pela OMC, são "most intensively used against developing countries and transition economies" (Laird, 1996: 11).

A idéia principal por trás das negociações do GATT/OMC é reduzir e consolidar (bind) tarifas concedidas com base no princípio da nação mais favorecida (MFN), criando com isso maior acesso a todos os países membros. Como afirma o mesmo estudo, "increasing the extent of bindings was one of the main objectives of the Uruguay Round, and the major result was the very substantial increase in bindings by developing countries" (Laird, 1996: 2).

Em termos tarifários, ainda de acordo com Laird (1996: 2), ao final da Rodada Uruguai (1994) o quadro era em resumo o seguinte:

\begin{abstract}
"developing countries cut their trade-weighted average bound MFN rates against imports from industrial countries from 14,9 to 10,7 per cent. This was made up mainly of cuts by Latin American countries, from 22,1 to 18,2 per cent, Asian countries, from 12,4 to 8,4 per cent, and developing Europe, from 26,4 to 15,5 per cent. African countries made no measurable cuts, retaining average bound rates at 23 per cent. Developing countries cut their trade-weighted average bound MFN rates on imports from other developing countries from 10,1 to 7,1 per cent".
\end{abstract}

Dados referentes aos níveis tarifários praticados no Brasil, no período de 1988 a 1994, detalhados abaixo, explicitam as conclusões apresentadas por Laird ao demonstrar a significativa redução nas tarifas externas praticadas no Brasil.

Tabela 7 - Imposto de importação no Brasil Alíquota média de 1988 a 1994

\begin{tabular}{|c|c|c|c|c|c|c|c||}
\hline Ano & $\mathbf{1 9 8 8}$ & $\mathbf{1 9 8 9}$ & $\mathbf{1 9 9 0}$ & $\mathbf{1 9 9 1}$ & $\mathbf{1 9 9 2}$ & $\mathbf{1 9 9 3}$ & $\mathbf{1 9 9 4}$ \\
\hline Alíquota Efetiva Média & $50,4 \%$ & $45 \%$ & $45,5 \%$ & $35,1 \%$ & $28,9 \%$ & $18,9 \%$ & $14,4 \%$ \\
\hline
\end{tabular}

Universitas - Relações Int., Brasília, v. 2, n.1, p. 59-101, jan./jun. 2004 
Um outro aspecto - que não pode ser considerado um fator de abertura, mas que trouxe importantes conseqüências na inserção dos países em desenvolvimento no comércio internacional - foi o aumento no fluxo de investimentos estrangeiros diretos (FDI), direcionados a esses países, a partir do início da década de 90. De acordo com estatísticas divulgadas pelo Fundo Monetário Internacional, em 1992 os mercados emergentes receberam, em termos líquidos, US\$ 35,7 bilhões em investimentos diretos privados. Em 1999, esse valor foi quatro vezes maior, e chegou a US\$ 154,6 bilhões ${ }^{19}$ (IMF, 2001: 65).

Em geral essas inversões realizaram-se, entre outros motivos ${ }^{20}$, pela busca de novos mercados, aproveitando algumas vantagens comparativas existentes nesses países associadas ao baixo custo de mão-de-obra, benefícios fiscais e abundância de recursos naturais, o que, por seu turno, transformou alguns desses países em plataformas exportadoras para suprimento de mercados regionais ou, até mesmo, do mercado mundial. Uma outra característica marcante desse novo ciclo de investimentos, com importantes conseqüências para a maior participação desses países no comércio internacional, foi a adoção de estratégias de conquista de mercados mundiais com segmentação da produção. Esse último aspecto desencadeou um novo processo de inserção dessas economias no comércio mundial que rompeu a estratégia, prevalecente especialmente na América Latina, de produção para o mercado interno com base em um modelo nacionalista de substituição de importações. Relatório do Banco Mundial (World Bank, 2000: 46) destaca essa relação existente entre investimento direto e aumento do comércio internacional, ao afirmar que:

\footnotetext{
${ }^{19}$ Apesar da diminuição no fluxo de capitais para países em desenvolvimento, entre 1998 e 1999, o fluxo de investimentos diretos para esses países se manteve com crescimento relativamente estável ao longo de toda a década de 90 (IMF, 2000, 96).

20 Entre esses outros motivos, merecem destaque os ajustes macroeconômicos realizados ao longo dos anos 90, que produziram uma grande quantidade de privatizações.
}

Universitas - Relações Int., Brasília, v. 2, n.1, p. 59-101, jan./jun. 2004 
"the acceleration of world import demand should also help to boost export-oriented FDI flows. In recent years, the fall in transportation and communication costs and the lowering of trade and other barriers to cross-border investments have increased the share of FDI directed toward global production networks - evident, for example, in the rising volume of exports that represent intrafirm transactions".

\section{III - O sistema multilateral de comércio e o artigo XXIV do GATT}

Apesar do enfoque do tópico anterior, o avanço verificado nos países em desenvolvimento não deve ser creditado exclusivamente à OMC. Boa parte da abertura comercial, verificada a partir dos anos 80 nesses países, só pode ser explicada por um processo de aumento no número de acordos regionais de comércio.

O acordo de estabelecimento do GATT, datado de 1947, estabeleceu diversos princípios que nortearam a linha de ação da OMC. Via de regra, esses princípios buscavam criar as condições necessárias para a conformação de um sistema multilateral de comércio transparente e equilibrado, que pudesse retornar os níveis de comércio aos patamares anteriores à Primeira Guerra Mundial. Dentre as diretrizes estabelecidas pelo GATT, destaca-se o princípio da nação mais favorecida $(N M F)$, considerado a espinha dorsal do sistema multilateral de comércio estabelecido no pós-guerra (Mello, 2003). Esse princípio, detalhado no Artigo I do acordo do GATT/1947 determina que os países signatários do acordo devem ser tratados de forma semelhante no comércio internacional ${ }^{21}$. Assim, qualquer tratamento favorável, vantagem, privilégio ou imunidade concedido a um país, para um determinado produto, deve ser obrigatoriamente

21 "With respect to customs duties and charges of any kind imposed on or in connection with importation or exportation or imposed on the international transfer of payments for imports or exports, and with respect to the method of levying such duties and charges, and with respect to all rules and formalities in connection with importation and exportation, and with respect to all matters referred to in paragraphs 2 and 4 of Article III, any advantage, favour, privilege or immunity granted by any contracting party to any product originating in or destined for any other country shall be accorded immediately and unconditionally to the like product originating in or destined for the territories of all other contracting parties." (WTO, 1999: 424 )

Universitas - Relações Int., Brasília, v. 2, n.1, p. 59-101, jan./jun. 2004 
estendido aos demais países signatários. Em sentido inverso, com base nesse princípio nenhum país signatário pode ser discriminado no comércio internacional. Dessa forma, preferências tarifárias negociadas entre dois ou mais signatários devem, necessariamente, ser estendidas aos demais.

Dentro de um cenário de comércio internacional fundamentado nesse princípio, as tarifas ou preferências de acesso que um país estabelecesse para um determinado produto seriam iguais para todos os países. Assim, as relações seriam equivalentes e não haveria preferências ou alíquotas diferenciadas entre os países signatários. Preferências tarifárias eventualmente negociadas entre dois ou mais países seriam automaticamente concedidas aos demais, fazendo com que, no fim do processo de negociação, cada país praticasse - para cada produto - uma única tarifa externa para o restante do mundo.

A despeito das dificuldades de implementação e de monitoramento, esse modelo funcionou com relativa eficiência durante cerca de 40 anos, possibilitando, conforme já visto anteriormente, um processo quase universal de abertura ao comércio internacional.

As regras que conformaram o sistema do GATT, e que estabeleceram o princípio da nação mais favorecida, também abriram a possibilidade de que os países realizassem acordos regionais de livre comércio (bilaterais ou multilaterais) que representassem um progresso em relação aos acordos celebrados na esfera multilateral. Em outras palavras, foram aceitos aqueles acordos de livre comércio que tivessem o objetivo de aprofundar as negociações realizadas no âmbito do GATT. Dessa forma, o Artigo XXIV do acordo do GATT (1947) formalizou a possibilidade de áreas de livre comércio e uniões aduaneiras $^{22}$ conformes às normativas da $\mathrm{OMC}$, ao estabelecer que:

\footnotetext{
22 Área de Livre Comércio é um acordo realizado entre dois ou mais países no qual se eliminam os direitos aduaneiros e outras restrições ao comércio exterior, exclusivamente para os países que celebraram o acordo. União Aduaneira é considerada por muitos autores uma etapa posterior à zona de livre comércio. Pressupõe, além da desgravação das tarifas e outras restrições ao comércio exterior, a adoção de uma tarifa externa comum e de políticas comerciais comuns. Dessa forma, os países contratantes liberalizam o comércio entre si, ao mesmo tempo em que adotam uma mesma tarifa externa e políticas comerciais comuns (política aduaneira, normas fitossanitárias, regras de origem, etc) frente ao restante do mundo.
}

Universitas - Relações Int., Brasília, v. 2, n.1, p. 59-101, jan./jun. 2004 
"the provisions of this Agreement shall not prevent, as between the territories of contracting parties, the formation of a customs union or of a free-trade area or the adoption of an interim agreement necessary for the formation of a customs union or of a free-trade area" (WTO, 1999: 458)

Entretanto, o próprio acordo do GATT estabelece que esses arranjos regionais só serão considerados compatíveis com as normas do sistema multilateral de comércio se um conjunto de condições forem cumpridas. Dentre essas condições, convém destacar que esses acordos (a) não devem provocar o surgimento de discriminações às demais partes contratantes; (b) devem abarcar o substancial do comércio, com desgravação desse substancial em até 10 anos; e (c) não podem implicar em retrocesso em relação aos termos já negociados no âmbito do GATT (WTO, 1999: 458).

Pela importância assumida em anos mais recentes, o Artigo XXIV, que autoriza a celebração de acordos regionais, merece uma análise mais detalhada. Esse artigo, ao autorizar a formação de áreas de livre comércio e de uniões aduaneiras, abre um novo leque de possibilidades nas relações comerciais internacionais. Com base nessa idéia, os países membros do sistema GATT/OMC não são mais obrigados a conceder um mesmo nível de acesso para todos os demais países membros, conforme determina o princípio da nação mais favorecida. Na prática, as condições de acesso aos diferentes mercados continuarão sendo pautadas pelos acordos realizados no âmbito multilateral. Entretanto, alguns países terão, por conta dos acordos regionais que venham a celebrar, acessos a determinados mercados em condições mais favoráveis que as de seus pares do GATT/OMC. Em sentido inverso, esses países concederão melhor acesso àqueles países com os quais tenha realizado acordos regionais fora da órbita do GATT/ OMC.

Diante dessa possibilidade de discriminação, abrem-se duas consequiências no tocante aos fluxos internacionais de comércio. A realização de acordos regionais pode funcionar criando comércio entre países (trade-creating) ou então desviando o comércio que antes era realizado com outras regiões (trade-diverting).

Universitas - Relações Int., Brasília, v. 2, n.1, p. 59-101, jan./jun. 2004 
A criação de comércio ocorre naturalmente tendo em vista alguns princípios econômicos, em especial a teoria das vantagens comparativas. De acordo com essa teoria, em uma situação de livre comércio com especialização da produção os países participantes passariam a produzir com maior eficiência aqueles produtos para os quais possuem maior vantagem de produção, o que aumentaria a riqueza mundial. Além dos ganhos advindos do aumento da produção total, a população também se beneficiaria de forma indireta pois, com a redução dos preços que a especialização da produção e o fluxo comercial proporcionariam, haveria um aumento dos salários reais ${ }^{23}$. Em resumo, em um cenário de abertura comercial entre dois ou mais países haveria, em teoria, ganhos de lado a lado e cada país se concentraria em produzir em sua área de vantagem comparativa (Samuelson, 1993: 769).

Essas proposições fundamentais do comércio e, especialmente, a teoria das vantagens comparativas, ajudam a explicar a importância dos acordos regionais de livre comércio como instrumentos de criação de comércio entre os países participantes. Dessa forma, pode-se esperar que em um cenário de abertura comercial entre dois ou mais países haja uma propensão à criação de comércio entre ambos, com possível crescimento na renda nacional. Esse, em resumo, é o fator principal que explica a autorização para a realização desses acordos, no âmbito do sistema GATT/OMC.

Um segundo aspecto relacionado ao estabelecimento de acordos de livre comércio, conforme dito anteriormente, é a possibilidade de que esses acordos venham a causar não apenas criação de comércio, mas também desvios de comércio. Nesse sentido, paralelamente ao processo de criação de comércio, descrito anteriormente, surge um natural ajuste nas trocas comerciais, em decorrência das novas condições criadas pelas negociações realizadas. Com isso, uma parte das exportações desloca-se para mercados que passaram a ter condições de acesso mais vantajosas, ao mesmo tempo em que as importações tendem a originar-se em maior medida

23 De acordo com Samuelson (1993, 769), os salários reais são calculados pelo montante de bens e serviços que um trabalhador pode comprar com a remuneração de uma hora de trabalho.

Universitas - Relações Int., Brasília, v. 2, n.1, p. 59-101, jan./jun. 2004 
daqueles países que obtiveram, de forma simétrica, acesso mais favorecido ao mercado doméstico.

Em outras palavras, diante da redução das tarifas e outros entraves ao comércio internacional, as exportações, que antes eram direcionadas a outros mercados, passam a migrar em maior número para os países com os quais foram celebrados acordos regionais, em virtude da obtenção de melhores condições de acesso. Da mesma forma, e em sentido inverso, as importações, antes provenientes de outros mercados, passam a originar-se em maior quantidade dos países que obtiveram de forma recíproca as melhores condições de acesso no mercado doméstico. Ao final desse processo, não ocorre apenas um aumento nos fluxos de comércio exterior, mas também um ajuste ou deslocamento que favorece, em maior medida, aqueles países que, em virtude dos acordos regionais de livre comércio, obtiveram - e concederam - condições favorecidas de acesso aos seus respectivos mercados.

Em conseqüência desse movimento de benefícios mútuos, em detrimento dos demais países, pode-se afirmar que os acordos regionais de livre comércio geralmente liberalizam o comércio intraregional, estabelecendo preferências ou vantagens entre seus participantes, ao mesmo tempo em que tornam comparativamente menos favorável o acesso de terceiros países. Por esse motivo, são freqüentemente desviadores de comércio, ao invés de serem criadores de comércio. Esse é o motivo pelo qual, para alguns autores, os arranjos em blocos comerciais não seriam casos de racionalidade econômica pura, mas de autoproteção pragmática (Pereira, 1996: 297).

A constatação de que os acordos regionais possam se converter em arranjos discriminatórios torna-se preocupante na medida em esses acordos ampliam-se de forma crescente no período mais recente. Conforme descrito no início do presente estudo, nos últimos anos verificou-se uma expansão no número desses acordos, que saltaram de 130 em 1995 para cerca de 250 em 2002 (WTO, 2003b: 1). Além disso, as perspectivas futuras indicam uma tendência de crescimento sem possibilidade de reversão (Bhagwati, 2003).

Diante desses fatos, surge a seguinte pergunta: se os acordos regionais causam distorções no comércio internacional, como explicar

Universitas - Relações Int., Brasília, v. 2, n.1, p. 59-101, jan./jun. 2004 
seu crescimento acelerado nos anos mais recentes? Em outras palavras, que fatores explicam a atual preferência por esses arranjos, a despeito do risco de erosão da OMC e dos prejuízos coletivos que eles provocam?

Evidentemente, os motivos que induzem à realização de acordos regionais não são uniformes, variando muito de caso a caso. Nessas decisões entram em jogo, além das perspectivas de ganhos no comércio internacional, aspectos locais relacionados a laços culturais ou estratégias diplomáticas de geopolítica, entre outros. Entretanto, esses aspectos são muitas vezes localizados ou conjunturais, e não traduzem uma tendência coletiva. Servem, portanto, como explicações para casos isolados, mas não permitem perceber os fatores que estão por trás da tendência global de multiplicação desses acordos.

$\mathrm{Na}$ busca pelos fatores que possam explicar a proliferação dos acordos regionais, o presente estudo irá dedicar especial atenção a três. São eles a multiplicidade de novos temas, atualmente presentes nas negociações da OMC, a significativa mudança no cenário internacional, a partir do início dos anos $90 \mathrm{e}$, por último, a maior flexibilidade que os acordos regionais oferecem em uma negociação em dois níveis.

\section{III.1 - A OMC e os novos temas}

As negociações de liberalização comercial, levadas a cabo no pós-guerra, conforme visto anteriormente, concentraram-se em grande medida na eliminação de "impostos de importação" e de outros entraves ao comércio de bens. Assim, boa parte dos avanços obtidos nas rodadas de negociação das décadas de 50, 60 e 70 realizaram-se com o foco principal de eliminar "tarifas", ou "impostos de importação", à entrada de produtos estrangeiros. Como resultado, no início da década de 80 a maior parte dos países desenvolvidos contava com alíquotas de "imposto de importação" muito próximas de zero para uma grande parcela de seu universo tarifário. As poucas exceções ficavam por conta de produtos para os quais - por questões diversas -

Universitas - Relações Int., Brasília, v. 2, n.1, p. 59-101, jan./jun. 2004 
alíquotas mais elevadas ou outras barreiras ao comércio foram mantidas ${ }^{24}$.

A partir do final da década de 80, entretanto, amplia-se a agenda das negociações comerciais internacionais, a partir da introdução de uma série de novos temas. Esses novos temas passaram a abarcar aspectos que, como o próprio nome diz, praticamente não eram discutidos antes no âmbito internacional. Dentre esses novos temas, conhecidos geralmente como Temas de Singapura, destacam-se questões relacionadas a defesa comercial, direitos trabalhistas, meio ambiente, propriedade intelectual, compras governamentais, serviços e investimentos ${ }^{25}$.

Com a inclusão desses novos temas, torna-se evidente o dissenso internacional e os avanços obtidos em décadas anteriores tornam-se difíceis de serem replicados. Aos países ricos, passa a interessar a liberalização em setores como investimentos e serviços, bem como um maior disciplinamento no tema de propriedade intelectual e compras governamentais. Nos países menos desenvolvidos, em sentido inverso, o pouco conhecimento adquirido sobre esses novos temas gera um sentimento de insegurança que dificulta o aprofundamento das discussões (Jonquières, 2003). Cria-se, portanto, uma percepção coletiva, nos países em desenvolvimento, de que eles não estão em condições de usufruir das vantagens oferecidas por uma maior abertura nessas áreas. Além disso, consolida-se gradualmente um sentimento de que os países menos desenvolvidos seriam "ofertantes" nesses novos temas e de que os países desenvolvidos, por sua vez, seriam os únicos que poderiam aproveitar de forma mais eficiente, sobretudo no curto prazo, os benefícios advindos da abertura nessas novas áreas.

Entretanto, a agenda dos países menos desenvolvidos na OMC, nos anos mais recentes, não foi uma agenda exclusivamente negativa.

\footnotetext{
${ }^{24}$ Nos países em desenvolvimento, conforme visto anteriormente, essas reduções foram mais modestas, acentuando-se apenas em anos recentes.

${ }^{25}$ Boa parte desses novos temas têm recebido a alcunha de Temas de Singapura em referência à Reunião Ministerial da OMC de 1996 que decidiu pela inclusão de alguns desses temas nas discussões multilaterais. Nesse encontro foram inseridos nas negociações os temas de investimento, política de defesa da concorrência, compras governamentais e facilitação de comércio
}

Universitas - Relações Int., Brasília, v. 2, n.1, p. 59-101, jan./jun. 2004 
A recusa desses países em discutir os chamados Temas de Singapura não significou que nada de novo interessava. Ao contrário, alguns temas antes ignorados nas rodadas anteriores da OMC, sobretudo aqueles relacionados à liberalização e disciplinamento do comércio agrícola, passaram a ganhar importância crescente nas prioridades dos países menos desenvolvidos. Nesse sentido, nos últimos anos os interesses dos países menos desenvolvidos se concentraram em questões que não são necessariamente novas, mas que possuem uma grande importância estratégica, como maior disciplina às medidas de apoio doméstico, disciplina às medidas de defesa comercial e a eliminação dos subsídios à exportação.

Nesse campo, também, as negociações mais recentes não apresentaram resultados concretos. Apesar da inclusão formal desses e de outros temas na agenda da OMC, os esforços dos países menos desenvolvidos em "destravar" as negociações nessas áreas foram mal sucedidos até o momento, por conta da forte resistência dos países desenvolvidos em disciplinar as medidas que distorcem o comércio internacional de produtos agrícolas.

Além disso, a insistência dos países ricos em discutir os novos temas torna mais difícil o equilíbrio de interesses de lado a lado, na medida em que avanços em uma área passam a ser condicionados a progressos em outra. Dessa forma, na prática um maior acesso a mercados dos países em desenvolvimento tem sido freqüentemente condicionado a uma revisão das políticas agrícolas de Estados Unidos, União Européia e Japão e, em sentido inverso, a revisão das políticas agrícolas nesses países é, muitas vezes, atrelada a discussões sobre qualidade ambiental, propriedade intelectual e padrões trabalhistas.

Nesse cenário em que tudo está vinculado a tudo, o avanço em qualquer tema torna-se um exercício de diplomacia que na maioria das vezes não produz resultados. A multiplicidade de temas e as associações que se estabelecem entre eles cria uma dificuldade sistêmica em obter consensos que torna as negociações realizadas no âmbito da OMC desgastantes e infrutíferas. Como resultado, a celebração de acordos regionais surge como uma das únicas alternativas viáveis para suplantar esse impasse e realizar aberturas comerciais em bases menos complexas. Nesses arranjos, a maior 
liberdade de manobra e o menor número de interesses a serem levados em conta torna a possibilidade de obter resultados concretos muito maior.

Em resumo, a multiplicidade de temas e a diversidade de interesses existentes no âmbito da OMC criam um cenário de conflito de interesses que dificulta o avanço das negociações. Nesse cenário, os acordos regionais de comércio surgem como uma das únicas alternativas viáveis para progressos em temas que encontram-se em situação de impasse no âmbito da OMC. O caráter mais limitado desses acordos, portanto, torna o exercício de negociação menos desgastante, o que se converte em um grande atrativo que explica, em parte, a multiplicação no número desses acordos em anos recentes.

\section{2 - Mudança no cenário internacional}

Um segundo fator que ajuda a explicar a recente proliferação de acordos regionais de livre comércio, em detrimento dos acordos celebrados no âmbito do sistema GATT/OMC, foi a mudança no cenário internacional, ocorrida em fins do século XX. Nesse período de profundas transformações políticas, que compreendeu o fim da década de 80 e toda a década de 90 , observa-se um desmantelamento das estruturas que sustentaram o modelo político socialista.

Nesses anos, manifesta-se um complexo conjunto de processos políticos que abriram gradualmente a chamada cortina de ferro, que separava o mundo socialista do mundo capitalista. Esses processos tiveram diversas consequiências imediatas, com destaque para duas. Em primeiro lugar, e de forma mais aparente, diminuem-se sensivelmente as tensões militares e ideológicas entre leste-oeste, que pautaram toda a política externa das grandes potências no pós-guerra. Com o fim da União Soviética e com as mudanças políticas nos países do leste europeu que conformavam o bloco socialista, iniciou-se um processo de distensão que teve como resultado prático mais visível a redução dos estoques mundiais de armas nucleares. Assim, o fim das hostilidades entre os dois blocos possibilitou o fim das tensões, com maior cooperação e estreitamento político entre o mundo capitalista e o antigo mundo socialista.

Universitas - Relações Int., Brasília, v. 2, n.1, p. 59-101, jan./jun. 2004 
Além dos naturais desdobramentos no campo político e militar, desenvolveram-se, também a partir desse período, uma série de novas relações comerciais entre países historicamente rivais. À aproximação política do final da década de 1980 seguiu-se uma aproximação comercial também crescente. Com isso os Estados Unidos, expoentes do modelo capitalista de produção, passaram a estreitar seus laços comerciais com a União Soviética e outros países socialistas, levando os valores de comércio bilateral a patamares significativos.

No caso da Rússia, o comércio com os Estados Unidos nos anos anteriores a 1989 era praticamente inexistente. Entretanto, com o fim da guerra fria aquele país passou a experimentar níveis crescentes de comércio com os Estados Unidos, o que fez com que, após o início da década de 90, se verificasse uma forte expansão das importações norte-americanas provenientes da Rússia, que saltaram de US\$ 480 milhões em 1992 para US\$ 6.824 milhões em 2002. Nesses dez anos, portanto, as compras norte-americanas provenientes da Rússia cresceram $1.320 \%$, conforme demonstram as tabelas a seguir.

Tabela 8 - Comércio dos Estados Unidos com a Rússia Exportações norte-americanas em US\$ milhões

\begin{tabular}{||c|c|c|c|c|c|c|c|}
\hline Ano & $\mathbf{1 9 8 9}$ & $\mathbf{1 9 9 2}$ & $\mathbf{1 9 9 4}$ & $\mathbf{1 9 9 6}$ & $\mathbf{1 9 9 8}$ & $\mathbf{2 0 0 0}$ & $\mathbf{2 0 0 2}$ \\
\hline Total & 0 & 2.097 & 2.578 & 3.340 & 3.584 & 2.318 & 2.398 \\
\hline
\end{tabular}

Fonte: US Government (2003)

Tabela 9 - Comércio dos Estados Unidos com a Rússia Importações norte-americanas em US\$ milhões

\begin{tabular}{||c|c|c|c|c|c|c|c||}
\hline Ano & $\mathbf{1 9 8 9}$ & $\mathbf{1 9 9 2}$ & $\mathbf{1 9 9 4}$ & $\mathbf{1 9 9 6}$ & $\mathbf{1 9 9 8}$ & $\mathbf{2 0 0 0}$ & $\mathbf{2 0 0 2}$ \\
\hline Total & 0 & 480 & 3.234 & 3.560 & 5.733 & 7.796 & 6.824 \\
\hline
\end{tabular}

Fonte: US Government (2003)

Essa aproximação comercial, entretanto, não ocorreu apenas com os países que abandonaram o modelo socialista de produção. $\mathrm{O}$ caso chinês é exemplar para demonstrar o pragmatismo comercial contemporâneo, e a capacidade do comércio em transpor barreiras

Universitas - Relações Int., Brasília, v. 2, n.1, p. 59-101, jan./jun. 2004 
ideológicas. A China, no final dos anos 80 (1989), exportava para os Estados Unidos US\$ 11.988 milhões em bens. Dez anos depois, esse valor praticamente multiplicou-se por dez, alcançando em 2002 mais de US\$ 125 bilhões (U.S. Government, 2003). Percebe-se, assim, da mesma forma que o verificado com a Rússia, que houve uma expansão significativa do comércio entre Estados Unidos e China ao longo da década de 1990, sobretudo no tocante às importações norteamericanas. Os quadros a seguir resumem o comércio entre Estados Unidos e China no período analisado.

\section{Tabela 10 - Comércio dos Estados Unidos com a China Exportações norte-americanas em US\$ milhões}

\begin{tabular}{||c|c|c|c|c|c|c|c||}
\hline \hline Ano & $\mathbf{1 9 8 9}$ & $\mathbf{1 9 9 2}$ & $\mathbf{1 9 9 4}$ & $\mathbf{1 9 9 6}$ & $\mathbf{1 9 9 8}$ & $\mathbf{2 0 0 0}$ & $\mathbf{2 0 0 2}$ \\
\hline Total & 5.807 & 7.469 & 9.286 & 11.977 & 14.257 & 16.253 & 22.052 \\
\hline
\end{tabular}

Fonte: US Government (2003)

Tabela 11 - Comércio dos Estados Unidos com a China Importações norte-americanas em US\$ milhões

\begin{tabular}{||c|c|c|c|c|c|c|c||}
\hline Ano & $\mathbf{1 9 8 9}$ & $\mathbf{1 9 9 2}$ & $\mathbf{1 9 9 4}$ & $\mathbf{1 9 9 6}$ & $\mathbf{1 9 9 8}$ & $\mathbf{2 0 0 0}$ & $\mathbf{2 0 0 2}$ \\
\hline Total & 11.988 & 25.675 & 38.781 & 51.495 & 71.155 & 100.062 & 125.167 \\
\hline
\end{tabular}

Fonte: US Government (2003)

O estreitamento nas relações entre os Estados Unidos e seus antigos adversários criou um novo cenário político com fortes implicações na esfera comercial. Para os Estados Unidos e seus principais aliados, com o fim da guerra fria já não há mais a necessidade de manter uma coesão com vistas a combater um inimigo comum, como acontecia nas décadas anteriores. Com isso, o modelo multilateral de comércio concebido com base no GATT perde, aos olhos da potência hegemônica, uma parte importante de sua função.

Para o sistema GATT/OMC, a perda de importância aos olhos norte-americanos tem um efeito prático determinante. Como nação hegemônica e única potência global do pós-guerra, os Estados Unidos desempenham um papel decisivo no sucesso ou fracasso de qualquer

Universitas - Relações Int., Brasília, v. 2, n.1, p. 59-101, jan./jun. 2004 
política levada a cabo no cenário internacional. No caso do GATT, esse apoio foi ainda mais determinante por conta do estreito vínculo que essa organização teve com os princípios norte-americanos de liberdade, democracia e prosperidade. Por esses motivos, o fim do sistema político socialista na antiga União Soviética e nos países do Leste Europeu colocou em xeque boa parte do interesse ocidental - e sobretudo norte-americano - em manter um sistema multilateral de comércio relativamente universal e coeso.

Para que se entenda o peso que o poderio norte-americano teve na conformação do GATT, convém realizar uma rápida análise da participação dos Estados Unidos no cenário econômico internacional da década de 40. Ao final da Segunda Guerra esse país era, com larga margem de superioridade, o maior credor financeiro internacional. Além disso, era detentor do maior parque industrial do mundo, possuindo cerca de $2 / 3$ da produção industrial global (Hobsbawn, 1995: 254). Em termos monetários, possuía quase $70 \%$ das reservas mundiais de ouro e o dólar americano era, conforme estabelecido em Bretton Woods, a única moeda conversível ao ouro. No campo militar, os Estados Unidos eram a nação capitalista que liderava, de forma quase isolada, a disputa com os soviéticos pela superioridade nuclear mundial.

Baseados nessas constatações, e na hegemonia britânica do século XIX, alguns cientistas políticos, como Keohane (1981), têm proposto que a existência de nações hegemônicas (hegemon), como os Estados Unidos, proporcionaria as condições para o surgimento de ordens econômicas baseadas em regras estáveis e universais, a partir das quais o desenvolvimento econômico mundial se veria estimulado. Dentro desse mesmo raciocínio, a supremacia britânica do século XIX explicaria, em parte, o sucesso da primeira onda de liberalização comercial descrita anteriormente.

Ainda de acordo com essa corrente teórica, a existência de um hegemon como os Estados Unidos, e a crença de que os interesses de segurança nacional seriam mais bem atendidos por políticas liberais de comércio, favoreceu o estabelecimento de laços comerciais mais profundos com os países capitalistas, estimulando o fortalecimento do GATT e o conseqüente desenvolvimento do comércio mundial a níveis

Universitas - Relações Int., Brasília, v. 2, n.1, p. 59-101, jan./jun. 2004 
sem precedentes. Nesse cenário, aspectos políticos e estratégicos relacionados à Guerra Fria também estavam em jogo pois, como afirmou Bhagwati, os líderes norte-americanos, diante da ameaça soviética, entendiam que "os custos políticos domésticos da liberalização seriam compensados por ganhos no campo da política externa" (Bhagwati, 1989).

Com fim do conflito leste-oeste, e da conseqüente ameaça socialista, desaparece grande parte do estímulo ocidental - e sobretudo norte-americano - em manter um sistema multilateral de comércio baseado em regras comuns. Nesse momento torna-se mais interessante, sobretudo para as nações com maior poder de barganha, a realização de acordos bilaterais ou multilaterais de menor escopo. Em outras palavras, na medida em que os objetivos de segurança nacional perdem espaço, ganham terreno os objetivos de maior prosperidade econômica, que, no caso norte-americano e de outras nações desenvolvidas, encontram nos acordos localizados um espaço propício para o exercício da supremacia econômica.

Uma vez que as ações na esfera comercial não necessitam mais ser pautadas por um princípio comum, com o objetivo de manter a coesão política e ideológica do mundo ocidental, os Estados Unidos e as demais potências econômicas do mundo capitalista se vêem, a partir do início da década de 1990, com liberdade para conduzirem ações no campo comercial que maximizem seus respectivos interesses. Dessa forma, ao invés de cumprirem um ritual de concessões e barganhas em uma esfera multilateral, que se justificavam em grande medida por conta da ameaça de um inimigo comum, com o fim da guerra fria os Estados Unidos e outras potências econômicas optam por um caminho mais cômodo de realização de acordos regionais, que proliferam de forma intensa a partir do início dos anos 90.

\section{III.3 - Acomodação de interesses domésticos e a análise em dois níveis}

Decorrente em grande medida dos dois fatores analisados anteriormente, um último aspecto que favorece a proliferação de acordos regionais na atualidade é a capacidade desses arranjos 
localizados de acomodar de forma mais adequada os diferentes interesses domésticos.

Boa parte das análises sobre negociações comerciais externas, sobretudo aquelas baseadas em pressupostos realistas, enxergam os Estados como estruturas monolíticas dotadas de uma vontade única (Viotti, 1993). Esses estudos, entretanto, ignoram o fato de que a política externa é, na maioria das vezes, o resultado de um processo dinâmico de acomodação de interesses domésticos e que são esses interesses internos que, em essência, irão conformar a política externa de um país. Percebe-se, portanto, que um bom entendimento da dinâmica de negociações externas requer uma atenção aos processos internos de negociação pois são eles, em última instância, que irão pautar o comportamento do país no nível externo.

A partir dessa idéia, Robert Putnam (1993) desenvolveu estudos que demonstram que as negociações internacionais podem ser segmentadas em dois níveis, sendo um interno, ou doméstico, e outro externo, ou internacional. Esse autor afirma que a percepção da existência desses dois níveis, denominados por ele de nível 1 (externo) e nível 2 (doméstico), é fundamental para uma correta análise do processo de negociação política no cenário internacional, uma vez que na maioria das vezes esses dois níveis exercem uma forte influência entre si. Além disso, via de regra o nível doméstico (nível 2) condiciona de forma marcante a postura que o país assumirá nos foros internacionais.

A partir das idéias de Putnam de um modelo de dois níveis, é possível identificar o nível 1 das negociações comerciais, ou nível externo, como sendo o dos órgãos decisórios e de solução de contenciosos, no âmbito dos quais se estabelecem as regras internacionais de comércio e nos quais se equacionam as disputas comerciais. Para os objetivos do presente estudo, o nível 1 pode ser identificado, em termos concretos, como a Organização Mundial do Comércio (OMC) e os demais sistemas regionais de comércio.

Ainda com base nesse mesmo modelo, o nível 2, ou nível interno, seria representado pelos canais domésticos de negociação. Esses canais - nem sempre estabelecidos formalmente - seriam os núcleos que elaboram a política comercial externa de um país, e nos 
quais interagem os diversos atores ou agrupamentos envolvidos. Além disso, conforme dito anteriormente, o nível 2 elabora e condiciona as posições de um país nas negociações externas, fornecendo inclusive a margem de manobra de que dispõe o negociador.

Nas negociações comerciais, é possível identificar quatro grandes agrupamentos que normalmente compõem o nível 2. São eles o setor doméstico com potencial de ganhos nos processos de abertura comercial, o setor doméstico com potencial de perdas nos processos de abertura comercial, o Estado, representado pelos estratos políticos e pela burocracia governamental ${ }^{26}$ e, por último, a sociedade civil, com destaque para os sindicatos, as organizações não-governamentais e 0 setor acadêmico.

Conforme dito anteriormente, o modelo elaborado por Putnam é diferente dos modelos de análise tradicionais, especialmente daqueles baseados em pressupostos realistas, que enxergam o Estado como ator unitário e que, por isso, concentram suas análises no processo de tomada de decisão por parte desse ator (Viotti, 1993). Putnam, ao contrário dos modelos tradicionais, ressalta a importância de que ambos os níveis de análise sejam levados em consideração, por conta da influência mútua que exercem e por conta do forte papel que o nível interno exerce sobre as posições que o país assumirá nas negociações externas. Nesse caso, afirma o autor, a postura de um país no nível internacional será quase sempre o resultado das disputas e restrições que se estabelecem no nível doméstico (Putnam, 1993: 13).

Com base nessas idéias, convém analisar as negociações que se desenvolvem no âmbito da OMC a partir de uma ótica de dois níveis. Nessa organização, a relação entre os dois níveis de análise assume uma grande complexidade uma vez que (a) há uma grande quantidade de temas em discussão e (b) há um grande número de interesses divergentes em jogo. Nesse cenário, a acomodação das condicionalidades do nível doméstico (nível 2) com o cenário dinâmico das negociações no cenário internacional (nível 1) torna-se algo extremamente complexo. Os negociadores, ao mesmo tempo em que são obrigados a respeitar o mandato recebido em seus respectivos

\footnotetext{
${ }^{26}$ O termo "burocracia" é aqui utilizado com base na definição de Max Weber, significando, em resumo, o quadro ou estrutura funcional do estado.
}

Universitas - Relações Int., Brasília, v. 2, n.1, p. 59-101, jan./jun. 2004 
países, são obrigados também a lidar com interesses divergentes, ou mesmo antagônicos, de uma grande quantidade de interlocutores externos $^{27}$. O resultado final, nesses casos, é quase sempre uma grande dificuldade em alcançar resultados satisfatórios a todos os participantes. Nesse cenário de multiplicidade de atores e de interesses, os avanços coletivos ficam quase sempre aquém das ambições isoladas de cada participante.

Além disso, e mais importante, a relação entre essas duas dimensões de análise tem sido profundamente afetada pelo recente processo globalização. Por meio desse processo, produziu-se um aumento na velocidade institucional, o que gerou uma multiplicação e uma maior capacitação dos atores não-estatais envolvidos nas discussões de comércio exterior, em especial daquelas realizadas no nível 2 (Keohane, 2000: 114). Por meio da redução nos custos de transmissão de informações, novos setores domésticos incorporaram-se às negociações externas, participando de forma ativa do processo negociador com a busca de informações, estabelecimento de agendas, apresentação de posições e, sobretudo, cobrança de resultados. O processo da globalização, portanto, traz mais um complicador ao relacionamento entre os dois níveis, na medida em que os atores nãoestatais, por conta do processo de globalização, colocam-se em uma posição privilegiada para acompanhar as ações do governo e influir nas negociações de comércio exterior.

Por outro lado, em um cenário de acordos regionais com um número menor de países, as negociações externas (do nível 1), se analisadas também por um prisma de dois níveis, oferecem possibilidades mais concretas de alcance dos objetivos traçados no nível doméstico (nível 2). Nesse cenário com um número limitado de interlocutores, a acomodação de interesses torna-se mais factível uma

27 A fim de contornar essa dificuldade, nas negociações externas muitos países terminam por associar-se na formação de grupos de negociação. Essa opção, além de tornar a negociação mais "administrável", uma vez que reduz significativamente o número de jogadores, torna maior o poder de barganha desses países, pois o grupo representa a posição de um conjunto de países, e não apenas de um país isoladamente. O revés, nesses caso, é que na maior parte dos casos os países são obrigados a ceder parcialmente em suas posições a fim de acomodar interesses e estabelecer o consenso dentro do grupo.

Universitas - Relações Int., Brasília, v. 2, n.1, p. 59-101, jan./jun. 2004 
vez que não é necessário estabelecer um complexo jogo de barganhas, a exemplo do que normalmente acontece em um cenário de negociações multilaterais com grande número de atores. Assim, a menor quantidade de pontos sensíveis em jogo torna o exercício de negociação mais fluido e com maior possibilidade de resultados.

Além disso, as negociações bilaterais permitem ampliar ou reduzir o escopo de negociação, como forma de acomodar os interesses dos atores do nível 2, tornando as diretrizes emanadas desse nível mais fáceis de serem cumpridas. Seguindo essa idéia, os acordos regionais de comércio celebrados por países menos desenvolvidos via de regra não abarcam discussões sobre os chamados "novos temas", que atualmente interessam em maior medida aos países desenvolvidos ${ }^{28}$. Essa possibilidade de redução do espectro de negociação tem permitido, portanto, avanços de abertura de mercado em bases regionais que não seriam possíveis em um cenário multilateral.

As idéias expostas até aqui podem transmitir a impressão de que os acordos regionais poderiam ser moldados a critério dos países negociadores e que esses acordos seriam, via de regra, menos abrangentes do que aqueles celebrados no âmbito da OMC. Embora a primeira constatação seja verdadeira em parte, a segunda nem sempre se manifesta para os países desenvolvidos. Em verdade, a maior parte dos acordos regionais atualmente negociados pelos países desenvolvidos propõem um avanço em relação ao que já existe na OMC. No caso dos acordos celebrados por esses países, percebe-se um interesse manifesto em negociar os "novos temas", por conta do reduzido progresso nas discussões multilaterais ${ }^{29}$.

Os acordos regionais não seriam, portanto, uma opção em que são necessariamente reduzidas as ambições e os temas em discussão. Ao contrário, são mecanismos por meio dos quais são criadas possibilidades de progressos em temas de interesse do nível 2, ou nível doméstico, que não possuem boas perspectivas de tratamento no

\footnotetext{
${ }^{28} \mathrm{Um}$ exemplo concreto desse fato seriam os recentes acordos celebrados entre Mercosul e Comunidade Andina, que tratam basicamente de acesso a mercados, sem discussão substantiva em relação a outros temas que fazem parte da agenda multilateral

${ }^{29} \mathrm{Um}$ exemplo é o recente acordo de livre comércio entre Estados Unidos e Chile.
}

Universitas - Relações Int., Brasília, v. 2, n.1, p. 59-101, jan./jun. 2004 
âmbito da OMC. Em outras palavras, os acordos regionais, além de expandirem o comércio entre os países, criam também a possibilidade de pegar um "atalho" nas negociações multilaterais, disciplinando e liberalizando, de forma localizada, temas de interesse interno que não têm boa acolhida nas negociações multilaterais.

Essa maior margem de flexibilidade que os acordos regionais oferecem, permitindo que os termos de negociação sejam "moldados" de acordo com os interesses dos níveis 2 de lado a lado, traz também um viés de pragmatismo negociador que não pode ser ignorado. Conforme Bhagwati (2003) destaca, ao colocarem frente a frente países com interesses divergentes, sem o arbítrio de um órgão regulador, os acordos regionais também expõem os países a negociações internacionais em bases desequilibradas. Dessa forma, sentam-se em lados opostos da mesa países com indicadores econômicos extremamente desiguais. Nesse cenário, os países mais desenvolvidos encontram um terreno propício para impor preferências ou exigências que não teriam acolhida nos fóruns multilaterais. Ainda de acordo com Bhagwati, a perspectiva de ganhos nos grandes mercados têm levado muitos países, sobretudo as economias menores, a aceitar nas negociações regionais exigências que não seriam aprovadas em um cenário multilateral. $O$ resultado final é um enfraquecimento da posição desses países na $\mathrm{OMC}$, pois se eles "cederam a essas exigências em acordos bilaterais, certamente vão fazer o mesmo nas negociações da OMC" (Mello, 2003: 2).

Dentro do enfoque de Putnam de uma análise em dois níveis, uma outra característica dos acordos regionais, que explica a preferência recente por esse tipo de mecanismo, é a possibilidade de acomodar interesses do setor 2 pela adoção de barreiras técnicas ou, sobretudo, de regras de origem preferenciais ${ }^{30}$. Por meio das regras de origem, os países que celebram um acordo regional podem defender

\footnotetext{
${ }^{30}$ São regras negociadas no âmbito de acordos de livre comércio que buscam separar os países que realizaram um acordo de livre comércio dos demais países. Em outras palavras, as regras de origem preferenciais são o instrumento utilizado para determinar as condições necessárias para que os produtos dos países que celebraram o acordo possam gozar das preferências negociadas.
}

Universitas - Relações Int., Brasília, v. 2, n.1, p. 59-101, jan./jun. 2004 
seus interesses setoriais da concorrência externa, ou mesmo estimular um determinado setor a expandir-se, com a elaboração de condições que os produtos devem cumprir para serem considerados regionais e, por isso, gozarem das preferências negociadas. Com base nesse mecanismo, as pressões e os interesses do nível 2 podem ser facilmente acomodados, seja para favorecer a penetração nos mercados externos, seja para a proteção à entrada de produtos estrangeiros.

As regras de origem, portanto, reforçadas por regras de acesso negociadas numa base bilateral, permitem que as negociações no nível 1 acomodem mais facilmente os interesses e pressões do nível 2. Com isso, é possível obter maior proteção aos setores sensíveis, frente à competição externa. Nesse caso, agentes econômicos com maior risco de perda, por conta do processo de negociação externa, podem reverter os possíveis efeitos negativos da abertura comercial com a definição de regras de origem elaboradas sob medida para a proteção dos seus respectivos interesses ${ }^{31}$.

Além disso, conforme explica Krishna (2003: 4), as regras de origem específicas também possibilitam, na prática, a criação de reservas de mercado para determinados setores frente à competição externa. Essa reserva de mercado se materializaria, sobretudo, diante das exigências, normalmente presentes em regras de origem preferenciais, de aquisição de matérias-primas e bens intermediários a partir de fornecedores regionais. Assim, regras de origem exigentes ou elaboradas sob medida, que na prática não poderão ser cumpridas por produtores de fora da região, são usadas para acomodar as condicionalidades externadas no nível 2. O resultado prático é a criação de uma reserva de mercado para determinados produtores, frente a competidores de fora do acordo regional

Em conclusão, portanto, percebe-se que os acordos regionais de livre comércio possuem características que tornam mais fácil a satisfação dos interesses internos, se comparado ao intrincado processo das negociações realizadas no âmbito da OMC. A possibilidade de moldar o acordo, com base nos interesses de lado a lado, permite que

\footnotetext{
${ }^{31}$ De acordo com Krishna, (2003) no acordo do NAFTA há uma série de exemplos de regras de origem elaboradas sob medida para a proteção de um determinados setores produtivos
}

Universitas - Relações Int., Brasília, v. 2, n.1, p. 59-101, jan./jun. 2004 
se acomodem os interesses nacionais de forma mais adequada, sejam esses interesses os de maior acesso aos mercados externos ou de maior proteção à competição internacional.

\section{Conclusão}

A realização de acordos regionais, embora autorizada pelas normas da OMC, têm sido vista com preocupação por estudiosos da área de comércio exterior. Conforme demonstrado ao longo do presente estudo, a proliferação dos acordos regionais estaria provocando o surgimento de um caos sistêmico, que erode lentamente os fundamentos da Organização Mundial de Comércio, com destaque para o princípio da nação mais favorecida. De acordo, ainda, com essa visão crítica, o grande número de acordos regionais de comércio estaria provocando o surgimento de um sistema que se assemelha a "uma travessa cheia de espaguete emaranhado" (Mello, 2003), por tornar inadministrável o sistema que se forma.

Ao longo do presente estudo, foram analisadas as causas que provocam o surgimento e a proliferação, em anos mais recente, dessa modalidade de acordo. Para tanto, foram realizadas análises que buscaram mapear os diferentes ciclos ou "ondas" de liberalização comercial, ocorridas nos últimos dois séculos. Nessa análise, foi concedido um especial destaque à inserção dos paises em desenvolvimento no comércio internacional, por serem esses países os mais potencialmente afetados pelos efeitos negativos provocados pela realização de acordos regionais em larga escala (Bhagwati, 2003).

Por fim, o presente estudo buscou determinar os fatores que contribuem para a proliferação dos acordos regionais nos anos mais recentes. Obviamente, uma grande quantidade de fatores estão em jogo nas opções por essa modalidade de negociação, inclusive estratégias de caráter geopolítico que, por sua complexidade e especificidade, não foram aqui analisadas. Embora seja impossível mapear todos esses fatores, um maior destaque foi concedido a três deles, por sua abrangência e importância na proliferação de acordos regionais, em anos recentes.

Universitas - Relações Int., Brasília, v. 2, n.1, p. 59-101, jan./jun. 2004 
Um primeiro fator destacado foi a recente tendência, observada no âmbito da OMC, de multiplicação dos temas em discussão. Nesses sentido, foi demonstrado que o surgimento dessa multiplicidade de temas - sobretudo os chamados Temas de Cingapura -torna o consenso na OMC cada vez mais difícil. Diante dessa dificuldade, os acordos regionais surgem como uma opção pragmática que permite avanços limitados mas que, em determinadas circunstâncias, tornam-se de grande importância econômica e estratégica.

Um segundo fator destacado para a dificuldade de avanços na OMC, e para a recente tendência de proliferação de acordos regionais, foi o fim da guerra fria. Com o colapso do sistema soviético, os interesses ocidentais - e sobretudo norte-americanos - de manutenção de um sistema de comércio universal e coeso também se diluem. No cenário de distensão que caracterizou a década de 90, os custos de manutenção de um sistema multilateral de comércio deixam de interessa à potência dominante, o que, por sua vez, coloca os acordos regionais em uma posição de destaque para o alcance dos objetivos de livre comércio.

Por último, o modelo de análise em dois níveis de Robert Putnam foi utilizado para demonstrar que os acordos regionais tornam mais fácil a tarefa de acomodar os interesses domésticos, que se tornam mais complexos e dinâmicos em um cenário de globalização crescente. Dessa forma, esses arranjos ad hoc permitem uma melhor negociação dos interesses e das sensibilidades de lado a lado, com a criação de regras de acesso mais favoráveis que as da $\mathrm{OMC}$, em algumas circunstâncias, e com o estabelecimento reservas de mercado, em outras.

Após esse conjunto de análises, conclui-se que o processo de criação de acordos regionais têm sido motivado por fatores que vão além do mero estabelecimento de normas na arena internacional. Por trás do maior número desses acordos, em anos recentes, tampouco estão fatores conjunturais relacionados a variações temporárias nas tendências internacionais, ou a ajustes domésticos localizados que buscam acomodar ou reagir aos movimentos externos. Em verdade, os três fatores que alavancam a adoção crescente desses acordos, conforme visto ao longo do presente estudo, possuem características

Universitas - Relações Int., Brasília, v. 2, n.1, p. 59-101, jan./jun. 2004 
estruturais de longa duração, afetando as bases ou os fundamentos do sistema multilateral de comércio em seus níveis mais profundos.

Por esses motivos, é impossível supor uma reversão nessa tendência no curto prazo. Ao contrário, é cada vez mais provável que se consolide essa modalidade de acordo nas futuras negociações de liberalização comercial, tendo em vista, conforme detalhado ao longo do presente estudo, as vantagens que essa modalidade de acordo oferece. Assim, pode-se afirmar com relativa segurança que a tendência futura não é de uma padronização ou de uma redução no número desses acordos regionais mas, antes, de sua diversificação e ampliação.

Se por conta disso entraremos em um cenário de caos sistêmico ou em um modelo de negociação em que os poderosos se imporão sobre os países mais fracos, só o tempo poderá dizer. Mas é certo que, no atual ritmo de avanço, em breve será necessário reavaliar o papel da OMC no novo sistema internacional de comércio que se desenha. A grande questão, nessa futura discussão, é saber se prevalecerão as forças centrípetas pró-OMC, que pregam a existência de um eixo fortalecido com centralização das decisões em matéria de comércio internacional, ou se prevalecerão os interesses centrífugos, que percebem na proliferação de acordos regionais, com consequiente pulverização de decisões, um ambiente mais favorável para o alcance dos seus objetivos.

\section{Referências Bibliográficas:}

AZEVEDO, André Filipe; PORTUGAL, Marcelo. Abertura Comercial Brasileira e Instabilidade da Demanda de Importações. TR5Disponível em: http://www.ufrgs.br/ppge/pdf/ msp/97-05.pdf. Acesso em: 13.10.2003

BHAGWATI, Jagdish; PANAGARIYA, Arvind. "Bilateral Trade Treaties Are a Sham". Financial Times, 13.07.2003. Disponível em: http://www.globalpolicy.org/globaliz/econ/2003/0714rta.htm Acesso em: 20.08.2003

BHAGWATI, Jagdish. Protecionismo versus Comércio Livre. Rio de Janeiro: Nórdica, 1989.

Universitas - Relações Int., Brasília, v. 2, n.1, p. 59-101, jan./jun. 2004 
CEPAL - COMISSIÓN ECONÓMICA PARA AMÉRICA LATINA Y

EL CARIBE. El Desafio de las Nueveas Negociaciones Comerciales Multilaterales para América Latina y el Caribe. Temas de Coyuntura ${ }^{\circ}$ 7. Santiago, Chile, 1999.

COLLIER, Paul; DOLLAR, David. Globalization, Growth, and Poverty: Building an Inclusive World Economy. Washington D.C.: Oxford University Press, 2001.

FEENSTRA, Robert. "Integration of Trade and Disintegration of Production in the Global Economy". In: KING, Philip (Org.). International Economics and International Economic Policy. San Francisco: Mc Graw Hill, 2000. p 145-159.

GONÇALVES, Reinaldo; BAUMANN, Renato; CANUTO, Otaviano et al. A nova economia internacional: uma perspectiva brasileira. 5 ed. Rio de Janeiro: Campus, 1998.

HOBSBAWN, Eric. A Era dos Extremos - O Breve Século XX 19141991. São Paulo: Companhia das Letras, 1995.

IMF - INTERNATIONAL MONETARY FUND. World Economic Outlook 2000. Disponível em: http://www.imf.org/ external/pubs/ft/weo/2000/01/ . Acesso em: 15.10.2001.

JONQUIÈRES, Guy de. "Crushed at Cancún". Financial Times, 15.09.2003. Disponível em: http://www.investmentwatch.org/ articles/ft16sep.html. Acesso em: 01.10.2003

KEOHANE, Robert; NYE, Joseph S. Globalization: What's New? What's Not? (And So What?). Foreing Policy nr. 119. Washington D.C., 2000. p. 104-119.

KEOHANE, Robert. "Economia Política Internacional da Década de 1980". In: INSTITUTE FOR CONTEMPORARY STUDIES California (org.). Tarifas, Quotas e Comércio: A Política do Protecionismo. Rio de Janeiro: Zahar Editores, 1981. p. 149 - 164.

KRISHNA, Kala. Understanding Rules of Origin. Pennsylvania State University. Junho de 2003. Disponível em: http://econ.la.psu.edu/ kkrishna/survey2.pdf. Acesso em: 11.09.2003

LAIRD, Sam. Multilateral Approaches to Market Access Negotiations. WTO Staff Working Paper, n TPRD-98-02. Genéve: WTO, 1998.

Universitas - Relações Int., Brasília, v. 2, n.1, p. 59-101, jan./jun. 2004 
MELLO, Patrícia Campos. "Acordos bilaterais são instrumentos dos EUA". Estado de São Paulo, 20.07.2003. Disponível em : http://www.estado.estadao.com.br/editorias/2003/07/20/ eco032.html. Acesso em: 05.10.2003

PEREIRA, Luiz Carlos Bresser. Crise Econômica e Reforma do Estado no Brasil - Para uma nova interpretação da América Latina. São Paulo: Editora 34, 1996.

PUTNAM, Robert. "Diplomacy and domestic politics: the logic of two-level games". In: EVANS, Peter; JACOBSON, Harold; PUTNAM, Robert. Double-Edged Diplomacy: an Interactive Approach. Berkley: University of California Press, 1993.

SAMUELSON, Paul; NORDHAUS, William. Economia. $14^{\circ} \mathrm{ed}$. Lisboa: McGraw-Hill, 1993.

U.S. GOVERNMENT. ITC Trade Dataweb. United States International Trade Commission. Disponível em: http://dataweb.usitc.gov. Acesso em: 30.09.2003

U.S. GOVERNMENT. GDP and Other Major NIPA Series Tables: 1929-99. Department of Commerce, Bureau of Economic Analisys. Disponível em: www.bea.doc.gov/bea/dn/st-tabs.htm. Acesso em: 19/08/2000.

WATHEN, Tom. "Um Guia para o Comércio e Meio Ambiente". In: GOVERNO DO ESTADO DE SÃO PAULO. Secretaria de Meio Ambiente (org.). Comércio e Meio Ambiente, Direito, Economia e Política. São Paulo: 1996. p. 21-30.

WORLD BANK. "Private Capital Flows to Developing Countries". In:_ Global Development Finance 2000. Washington, DC. p. $35-54$.

WTO - WORLD TRADE ORGANIZATION. Trade Statistics. Disponível

em http://www.wto.org/english/res e/statis e/statis e.htm. Acesso em: 03.10.2003a

WTO - WORLD TRADE ORGANIZATION. Regional Trade Agreements. Disponível em: http://www.wto.org/english/tratop e/region e/region e.htm. Acesso em: 01.10.2003b

Universitas - Relações Int., Brasília, v. 2, n.1, p. 59-101, jan./jun. 2004 
WTO - WORLD TRADE ORGANIZATION. Legal Texts: The Results of the Uruguay Round of Multilateral Trade Negociations. Cambridge: Cambridge University Press, 1999.

VIOTTI, Paul; KAUPPI, Mark. International Relations Theory: Realism, Pluralism, Globalism. 2 ed. New York: MacMillan, 1993.

Universitas - Relações Int., Brasília, v. 2, n.1, p. 59-101, jan./jun. 2004 